\title{
Filmowe impresje Andrzeja Własta
}

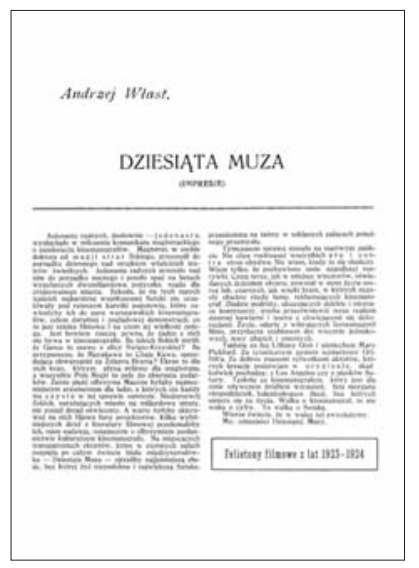

\section{MAŁGORZATA RADKIEWICZ}

Na okładce zbioru felietonów filmowych Andrzeja Własta zostało zamieszczone faksymile jego tekstu o strajku warszawskich kiniarzy, opublikowanego w podwójnym (8-9) numerze „Ekranu i Sceny" z 4 marca 1923 r. Pośród komentarzy interwencyjnych autora najmocniej wybrzmiewa końcowe stwierdzenie, że walka o kinematograf to walka o sztukę podjęta przez entuzjastów Dziesiątej Muzy. Do nich właśnie zaliczał się Włast, którego dorobek krytycznofilmowy z lat 1923-1924 został przez Wojciecha Świdzińskiego zebrany i opracowany naukowo w tomie Biblioteki Kwartalnika Filmowego. Konstrukcja zbioru skłania do dwojakiej lektury: diachronicznej - pozwalającej osadzić indywidualne doświadczenie filmowe, uchwycone w archiwalnych tekstach, w konkretnym czasie, przestrzeni i realiach dystrybucyjno-programowych; oraz kontekstowej - zmuszającej do spojrzenia na subiektywne zapiski przez pryzmat współczesnego autorowi życia kulturalnego, z jego lokalnym zróżnicowaniem, nurtami i modami. Na bogactwo kontekstów wyczula także we wstępie do felietonów Świdziński, zwracając uwagę, że kinofilska pasja Własta rozwijała się w modernizującej się Warszawie, funkcjonującej po 1918 r. jako miasto filmowe w prawdziwie europejskim stylu (s. 12). To właśnie obecność nowoczesnych kinoteatrów z aktualnym programem pozwoliła na polskim rynku prasowym zaistnieć takiemu tytułowi branżowemu, jak „Ekran i Scena", do którego redaktor Tadeusz Kończyc, krytyk i kierownik literacki teatrów, zaprosił Własta - równie wielkiego miłośnika Melpomeny, co i Dziesiątej Muzy. Warto zaznaczyć także kontekst rodzimej krytyki filmowej, tworzącej w dwudziestoleciu międzywojennym swoją tradycję, opartą na retoryce polemiczno-dydaktycznej - zwłaszcza gdy szło o kino polskie - oraz na oryginalnym stylu piszących intelektualistów i artystów.

Zresztą przeprowadzone przez Świdzińskiego paralele między biografiami Własta i skamandrytów - zwłaszcza Antoniego Słonimskiego, poruszającego w prasie podobne tematy - każą się doszukiwać w impresjach filmowych śladów wielorakiej działalności artystycznej i pasji literackiej. Zamieszczone we wstępie fragmenty utworów kabaretowych Własta nie pozostawiają wątpliwości co do jego potencjału twórczego jako felietonisty. Czytając monolog Lola Allegri, będący aluzją do kariery Poli Negri, od razu chciałoby się sięgnąć po Włastowskie recenzje jej filmów, by sprawdzić, czy również w nich pojawi się komentarz na temat statusu 
gwiazdy obśmianej jako „królowa kina”, która - jak przypomina we wstępie Świdziński - zwierza się: Mam gażę tausend mark / więc nie znam łez i skarg. / Zerwałam z polska kasta / wierzcie - Berlin to jest miasto (s. 19).

Z pewnością to właśnie temperament artystyczny Własta zadecydował o jego autorskim podejściu do tematów filmowych, które $\mathrm{z}$ humorem i uporem - jak temat strajku kiniarzy warszawskich - poruszał na łamach „Ekranu i Sceny”, równie błyskotliwie jak subiektywnie oceniając bieżący repertuar, jego twórców, widzów i całą instytucję kina. Nie stronił przy tym od skrajnych, kontrowersyjnych sądów, dla których znajdował usprawiedliwienie w przekonaniu, że: Trzeba sobie wreszcie uprzytomnić, że kinematograf przestał być humbugiem, businessem! Kinematograf to sztuka, przed która klękniecie jeszcze przechodnie w czapkach i kaloszach i która zmiecie was jak rewolucja, o rajcy miejscy od stuprocentowego podatku! [przyczyny wspomnianego strajku] (s. 54). Z wypowiedzi tej przebija ton edukacyjnopropagatorski, który Włast zawsze przybierał wtedy, gdy chodziło o sprawy artystyczne, związane ze stylem i środkami ekspresji filmowej, wymagające dostrzeżenia, zrozumienia i docenienia. Wyczuwa się go między innymi w tekstach poświęconych milowym, zadaniem felietonisty, dokonaniom takich reżyserów, jak David W. Griffith, którego uważał za mistrza „rytmicznych poematów”, całkowicie pozbawionych tak irytującej go teatralności. Po przeczytaniu recenzji Własta z Upadku Babilonu, czyli pokazywanego jako osobny utwór epizodu babilońskiego z Nietolerancji, nikt nie mógł mieć wątpliwości, że to dzieło największego z realizatorów filmowych (s. 85), obdarzonego talentem i oszałamiającą wyobraźnią. Podobny entuzjazm można odnaleźć w felietonie o filmie Szalone kobiety, w którym, mimo dość słabej fabuły i banalnego pomysłu, dostrzegł triumf reżyserii i inscenizacji Ericha von Stroheima. W opisie jego warsztatu, podobnie jak w przypadku Griffitha, pojawiają się uwagi na temat zawrotnego tempa i porywającego rytmu opowieści oraz umiejętnego wykorzystania zbliżeń, które - zdaniem piszącego są wymowniejsze niż wszystkie napisy (s. 119).

Zachwyty Własta nad kinem amerykańskim, pozostającym dla niego niedościgłym ideałem, jeśli chodzi o osiągnięcia przemysłu filmowego, rodzą pytanie o stosunek do dokonań innych kinematografii, również - choć wybiórczo i stronniczo, co zostaje zaznaczone już we wstępie do zbioru - na bieżąco przez niego komentowanych. Można więc tropić w felietonach wątek francuski, rosyjski, a nawet niemiecki, mimo wręcz demonstracyjnej niechęci autora do produkcji $\mathrm{z}$ tego kraju. W kilkakrotnie wspominanym Gabinecie doktora Caligari Roberta Wiene - dystrybuowanym w Warszawie dwukrotnie: w 1921 i 1924 r. - dostrzegł nawet doskonałe zespolenie podstawowych elementów kinematografu: scenariusza, dekoracji i interpretacji. Zaznaczył przy tym, że film ten nie tylko zyskał swoją $l i$ terature krytyczna, ale nawet stworzył pewien kierunek $w$ kinie (,,caligaryzm”) (s. 158), dając tym stwierdzeniem wyraz swojemu obeznaniu w zjawiskach awangardowych oraz bieżących publikacjach. Śledzenie fachowych opracowań można uznać za oczywiste świadectwo kinofilskiej pasji poznawczej Własta, jednak z drugiej strony była to oznaka wspólnej całemu środowisku krytycznofilmowemu dwudziestolecia międzywojennego potrzeby współuczestnictwa w tworzeniu refleksji na temat kina, jego estetyki i odbioru. Co ciekawe, Włast - mimo że prowadził rubrykę zatytułowaną Dziesiąta Muza - nie napomknął w niej w ogóle o ukazaniu się w 1924 r. książki Karola Irzykowskiego pod tym samym tytułem, a i ten nie wy- 
mienił z nazwiska autora tekstów z „Ekranu i Sceny” ", choć - zdaniem Świdzińskiego - to właśnie oni obaj przyczynili się do upowszechnienia i popularyzacji tytułowego określenia w polskiej kulturze filmowej.

Brak bezpośrednich odwołań nie oznacza, iż Włast i Irzykowski lekceważyli swoje publikacje, zwłaszcza że - jak pokazują materiały z lat 30. - polscy krytycy często podejmowali ze sobą dialog lub polemikę, ale raczej, że czytali je, po czym przyjmowali wobec nich pozę obojętności, eksponując tym samym własne przemyślenia. W trakcie przeglądania impresji Własta zwraca uwagę sposób konstrukcji argumentów, za pomocą których przekonywał on widzów o swoistości i walorach artystycznych sztuki filmowej, polegający zazwyczaj na dokonywaniu autorskiej definicji pojęć estetycznych albo terminów technicznych. Wyjaśniając istotę piękna w kinie, pisał o fotograficznej ścisłości akcji (s. 117), którą można osiągnąć przez matematykę ruchu i żonglerkę kontrastów (s. 118). Wskazywał przy tym na konieczność wypracowania przez reżyserów odpowiedniego warsztatu oraz umiejętność kinowego myślenia, którego oznaki - czasem tylko ślady - odnotowywał w recenzjach obejrzanych filmów. Luźna forma felietonu pozwoliła autorowi na równoczesne przekazywanie opinii krytycznych oraz na spontaniczne wypracowywanie języka, który nadążyłby za opisem zjawisk rozgrywających się na jego oczach: kinematograf to ciagła rewolucja, to rozpęd i burza (s. 124). Wybór tekstów z „Ekranu i Sceny” pokazuje, że choć Włast pisał je niespełna dwa lata, to jednak nawet w tak krótkim okresie był w nich w stanie uchwycić, jak żywa fotografia, jaką było kino na początku swego istnienia, stawała się poematem ruchu (s. 110). Czytelnicy „Ekranu i Sceny” wraz z nim poznawali istotę montażu oraz rytmu filmowego, przekonując się, że nożyczki reżysera kinowego (...) tworza, buduja (s. 59). Na podstawie emocjonalnych impresji Własta mogli również weryfikować swoje preferencje repertuarowe i obsadowe, zwłaszcza że jako doświadczony dyrektor artystyczny teatrów warszawskich przenikliwym okiem patrzył on na aktorów, a szczególnie na ich umiejętności dramatyczne i komiczne. Jego oceny sformułowane w kwiecistym stylu, niemal jak dowcipy kabaretowe, nie mogły pozostawić publiczności obojętną. Skłaniały ją do pójścia na kolejną produkcję z Mary Pickford, będącą po prostu geniuszem, przy którym Henny Porten jest tylko mdta mieszczka niemiecka (s. 47), albo z Rudolfem Valentino, łączącym urodę, zręczność $i$ siłę fizyczna, $z$ interpretacja skoncentrowana $w$ masce twarzy wyjątkowo fotogenicznej (s. 157). Z entuzjastycznymi opiniami Własta o filmach Charliego Chaplina raczej nikt nie polemizował, ale już jego bezkrytyczne podejście do ekranowych popisów Jackie’ego Coogana mogło budzić wątpliwości, zwłaszcza że - jak zauważa Świdziński - szanowani krytycy raczej tego dziecięcego aktora ignorowali albo wręcz odnosili się do jego kariery z niechęcią. Czytając opinie Własta, można się zastanawiać nad źródłami jego fascynacji filmowych i dziwić się dokonywanym wyborom, choć równocześnie trzeba docenić konsekwencję, z jaką opisywał swoje wrażenia i osobiste odczucia, nawet gdy miał świadomość, że mogą one odbiegać od powszechnie podzielanych opinii i gustów.

Entuzjastyczne zaangażowanie, z jakim Włast zapisywał swoje impresje, być może wynikało także z jego głębokiego przekonania, że swoim pisarstwem przyczyni się do zmiany nastawienia polskich widzów, a tym samym wpłynie na kondycję rodzimego kina. Ciekawe, że dekadę przed Stefanią Zahorską i jej postulatem edukowania publiczności „schodów kuchennych” także Włast, pisząc o mało wy- 
rafinowanych gustach bywalców kinowych, domagał się przede wszystkim ich edukacji. Zaznaczał również konieczność wymuszenia na twórcach i dystrybutorach odpowiedzialności za repertuar. Miał przy tym świadomość uwarunkowań ekonomicznych pozwalających funkcjonować tanim lokalom projekcyjnym, podporządkowanym regułom przedsiębiorstw widowiskowych, nie zważających na sztukę filmową. Jego stwierdzenie, że: Przyzwyczajono publiczność do pewnych kanonów estetycznych, przyzwyczajono ja do bezwstydnie kłamanych reklam (s. 87), nabiera głębszego znaczenia, gdy przeczyta się konkretne zarzuty, jakie stawia polskim produkcjom filmowym spod znaku Tajemnicy przystanku tramwajowego. Tytuł ten uznał za dowód dyletanctwa, stwierdzając, że bezczelność, z jaka kompromituje się u nas ekran, staje się zbrodnia, która powinna być karana przez kodeks (s. 124).

Jak na aktywnego miłośnika kina przystało, Włast nie ograniczał się jedynie do krytyki, próbując w swoich felietonach zawrzeć również konstruktywne rady i wskazówki. Najważniejsza dotyczyła zrozumienia fenomenu autorstwa filmowego oraz tego, że reżyser $w$ kinematografie to wielki potentat inwencji, często współautor $i$ właściwy twórca filmu (s. 132). Ślady takich autorskich postaw dostrzegł w zjawiskach i dokonaniach często zapomnianych albo marginalizowanych w historii polskiego kina, między innymi w twórczości bardzo przez niego cenionej Niny Niovilli, reżyserki, scenarzystki i producentki we własnej firmie Nina Niovilla-Film. Dokonany przez Własta opis tej postaci jako samodzielnej i wszechstronnej twórczyni może posłużyć jako przyczynek do studiów wypełniających lukę we wczesnej historii kina kobiet w Polsce. Uwagę Własta zwrócił także film Ślubowanie w reżyserii Zygmunta Turkowa, ze zdjęciami Seweryna Steinwurzela, będący po Dwóch światach kolejnym ciekawym obrazem życia żydowskiego. Felietonista docenił warsztat twórców oraz aktorów z teatrów żydowskich, uznając, że wszyscy oni dali poglądową lekcję naszym przemysłowcom i realizatorom, którzy własna nieudolność składają na karb braków technicznych i wykonawczych polskiego rynku filmowego (s. 153). Recenzja filmu stała się przyczynkiem do analizy rodzimej kinematografii z jej bolączkami, brakami, na które remedium, zdaniem autora, mogli być tylko kompetentni specjaliści: scenarzyści, montażyści, operatorzy.

Wybór impresji Własta, oprócz starannego opracowania naukowego, zyskał w edycji Biblioteki Kwartalnika Filmowego ciekawą oprawę graficzną, na którą składają się archiwalne zdjęcia, reklamy prasowe oraz oryginalna winieta „Ekranu i Sceny" poprzedzająca każdy z przedrukowanych tekstów. Książkę otwiera fotografia warszawskiego kina Bałtyk z ulicy Chmielnej - w latach 20. noszącego nazwę Palace - w którym Włast najchętniej zasiadał przed ekranem. Jest też kadr z wypełnionego tłumem holu Apolla, o którym Włast pisał jako o najohydniejszej budzie (s. 46). Dwa kolejne zdjęcia przypominają o dorobku Własta jako kierownika artystycznego warszawskich instytucji: Teatru Nietoperz oraz Kabaretu Morskie Oko, gdzie osiągał największe sukcesy. Można przypuszczać, że to właśnie praca w branży rozrywkowej wyczuliła go na sygnalizowane w felietonach kwestie rzetelnego opracowywania afiszy przez kierownika literackiego czy sposobu organizacji seansów. Książkę zamyka okładka ozdobiona zaczerpniętymi z „Ekranu i Sceny" reklamami filmowych szlagierów, którym Włast często zarzucał nieścisłości i konfabulacje zmieniające najpoetyczniejsze wizje ludzi sztuki na rynsztokowe dramaty detektywów i złodziei (s. 88). 
Felietony Własta nie zrewolucjonizowały polskiego kina, ale z pewnością miały odzew wśród współczesnych, o czym świadczy notka: Impresje moje wywołały ostatnio pewien sprzeciw na łamach prasy (s. 91). Okazuje się, że autorskie wypowiedzi wzbudzały emocjonalne reakcje, sprzeciwy i zarzuty o niekompetencję, które tylko podtrzymywały Własta w pisarskim zapale oraz zaangażowaniu w propagowanie Dziesiątej Muzy.

MAŁGORZATA RADKIEWICZ

Andrzej Włast, Dziesiąta Muza (impresje). Felietony filmowe z lat 1923-1924, wstęp i oprac. nauk. Wojciech Świdziński, Biblioteka Kwartalnika Filmowego, Instytut Sztuki Polskiej Akademii Nauk, Warszawa 2017.

${ }^{1}$ Zob. M. Radkiewicz, Dwugłos o X Muzie. Teksty filmowe Andrzeja Własta i Karola Irzykowskiego, „Pleograf. Kwartalnik Akademii Polskiego Filmu" 2019, nr 1, http://akademiapolskiegofilmu.pl/pl/historia-polskiego- filmu/pleograf/kino-przedwojenne/16/dwuglos-o-x-muzie-teksty-filmowe-andrzejawlasta-i-karola-irzykowskiego/669 (dostęp: 5.09.2019). 